\title{
Conservation status of the littoral forest of south-eastern Madagascar: a review
}

\author{
An Bollen and Giuseppe Donati
}

\begin{abstract}
The littoral forest of the Fort Dauphin region of south-east Madagascar is expected to lose numerous endemic plant and animal species in the near future as a result of deforestation and consequent habitat changes. The disruption of plant-animal interactions is of particular concern. This review describes the conservation status of the littoral forest of Sainte Luce, Fort Dauphin, and examines the role of animal-facilitated seed dispersal in regeneration. The main threats to this habitat are described and possible management implications are discussed in relation to existing initiatives. Protection of the largest remaining forest fragments has been agreed by local communities and a draft plan for forest management is currently under evaluation. Over the next few
\end{abstract}

years plantations will be created to provide local people with wood for fuel and other purposes. An important flying fox Pteropus rufus roost site needs to be included in conservation plans because of its importance for longdistance seed dispersal. Despite the presence of natural barriers, the creation of forest corridors will be crucial for connecting isolated fragments and facilitating genetic exchange between subpopulations. Increased attention needs to be given to the need to promote conservationrelated income activities.

Keywords Fort Dauphin, fragmentation, littoral forest, Madagascar, Pteropus rufus, Sainte Luce, seed dispersal.

\section{Introduction}

Madagascar is considered an important global conservation priority because of the high endemicity of its fauna and flora (Mittermeier et al., 1998; Dumetz, 1999) and the severe threats to the island's environment. Over $80 \%$ of the island has already been stripped of its native vegetation cover (Dupuy \& Moat, 1998). At current deforestation rates it is estimated that in 2025 forest will only remain on the steepest slopes and in remote areas and nature reserves (Green \& Sussman, 1990).

The littoral forest on sandy soils in the Fort Dauphin region is one of the most threatened Malagasy ecosystems, with $<2,835$ ha remaining (QMM, 2001). This forest type has been severely degraded and consists of many fragments, ranging in size from 1 to $377 \mathrm{ha}$. In the Fort Dauphin (Taolagnaro) area the remaining littoral forests on sandy soils form three groups of fragments, Petriky, Mandena and Sainte Luce (Fig. 1). Even though

An Bollen* (Corresponding author) Stationsstraat 27, B-3570 Alken Belgium. E-mail madana44@yahoo.com

Giuseppe Donati University of Pisa, Department of Ethology, Ecology and Evolution, Unit of Anthropology, Via S. Maria 55, 56126 Pisa, Italy.

*Also at: Centre for Research and Conservation, Royal Zoological Society of Antwerp, Koningin Astridplein 26, B-2018 Antwerp, Belgium.

Received 24 March 2004. Revision requested 19 October 2004. Accepted 8 March 2005. First published online 19 January 2006. the floristic composition of the forest in Sainte Luce and Mandena is similar, that of Sainte Luce has the highest species diversity and is one of the most intact littoral forests remaining in Madagascar (Rabevohitra et al., 1996; Dumetz, 1999). In a 377 ha forest fragment at Sainte Luce $98 \%$ of the 189 plant species are endemic to Madagascar (Rabevohitra et al., 1996; Razafimizanilala, 1996). At least 40 plant species are endemic to the littoral forest of the Fort Dauphin region (Lowry, 2001).

Here we review the conservation status of the littoral forest of Sainte Luce. The review is based on research carried out from September 1999 to February 2001 (Donati, 2002; Bollen, 2003), published information, personal communications from other field scientists, and our own personal observations. We focus on the causes of habitat loss and forest fragmentation, and highlight the importance of seed dispersal for landscape restoration. We also discuss ongoing conservation efforts in this region.

\section{Major threats}

Three villages, Ambandrika, Ampanasatomboky and Manafiafy are close to the largest forest fragments of Sainte Luce; S6 (147 ha), S7 (198 ha), S8 (129 ha), S9 (377 ha) and S17 (237 ha) (Fig. 2). Approximately 700 villagers depend on the forest for crop growing, timber and non-timber forest products for both subsistence and commercial activities. The main cause of forest loss in Sainte Luce, as elsewhere in Madagascar, is the practice 


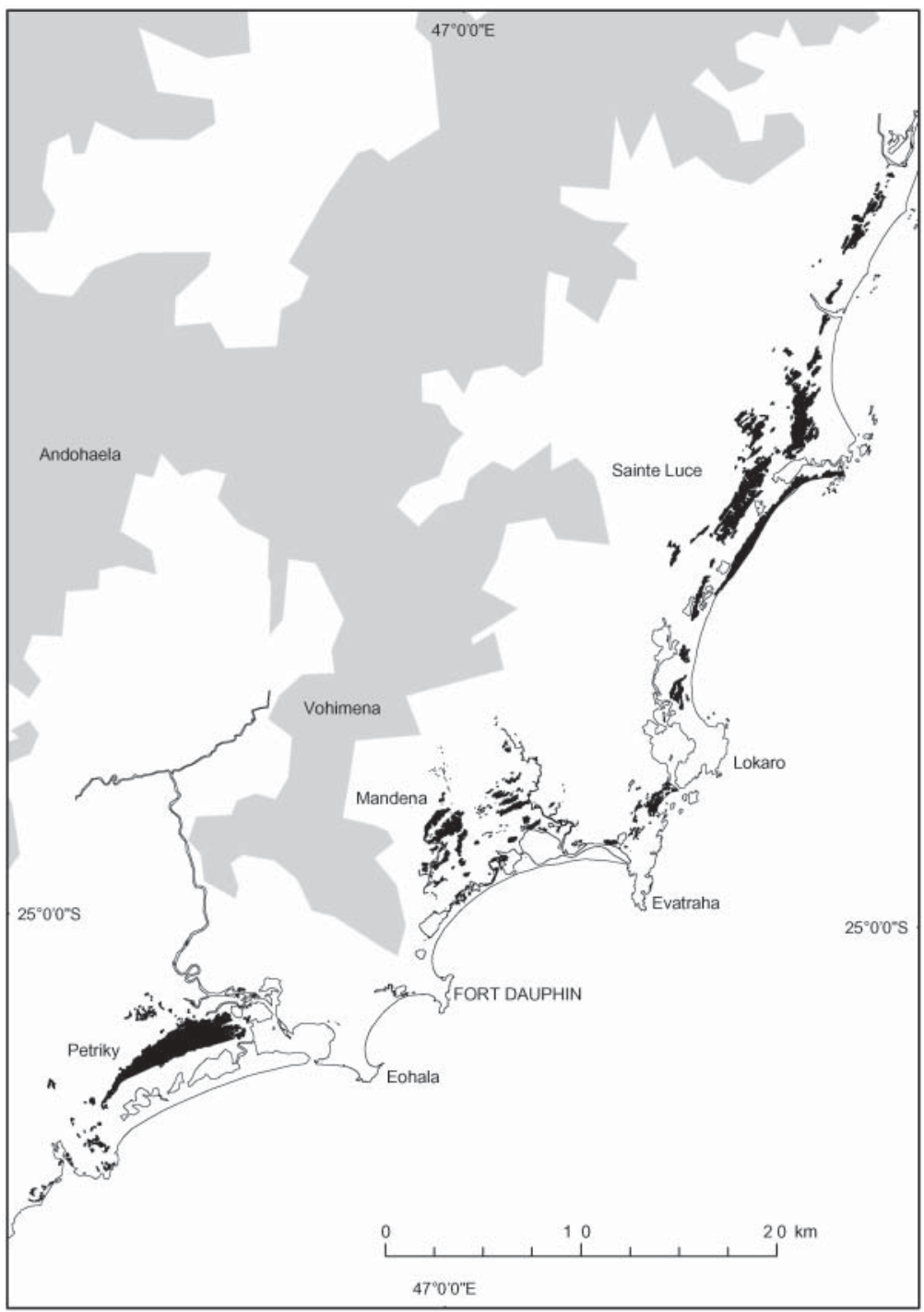

Fig. 1 The Fort Dauphin region of south-east Madagascar. The remaining littoral forests are indicated in black, and the humid montane rainforest in grey. of tavy (shifting slash-and-burn cultivation), which is often accompanied by bushfires. These bushfires are frequently uncontrolled, resulting in further deforestation. Tavy contributes directly to habitat loss, edge effects and soil sterilization. After clearance, grasslands develop in early successional stages and are later replaced by fireresistant shrublands dominated by invasive heath shrubs Erica spp. (Lewis Environmental Consultants, 1992).

Logging is another threat. People cut mainly large, mature trees for fuelwood, construction and tools. Because of the limited size of the forest fragments and the characteristic slow growth of most tropical tree species the current level of logging in the area appears to be unsustainable. Moreover, only parts of the felled trees are taken out of the forest, resulting in a wasteful use of resources (A. Bollen \& G. Donati, pers. obs.). Selective removal of timber and fuelwood has already changed the distribution pattern of some tree species (G. Donati, unpubl. data). Discussions with local people and observations of many trucks loaded with tree trunks lead us to the conclusion that some tree species, such as Cinnamosma madagascariensis, are already rare because of selective logging (G. Donati, pers. obs.). At the beginning of our research period logging only occurred for subsistence and on a local scale, but in December 2000 logging intensified and became more commercialized, apparently related to the growing need for wood in Fort Dauphin and the depletion of the forests closer to the city. The only wood people are legally allowed to take out of the littoral forest and without a permit is dead wood. However, people have been inventive in interpreting this law. They cut several trees in the forest, leave the logs there for a month, and afterwards collect this dead wood (G. Donati \& A. Bollen, pers. obs.). The villagers take several other products out of the forest. Large palms (Dypsis prestoniana and Dypsis saintelucei) are cut at the 


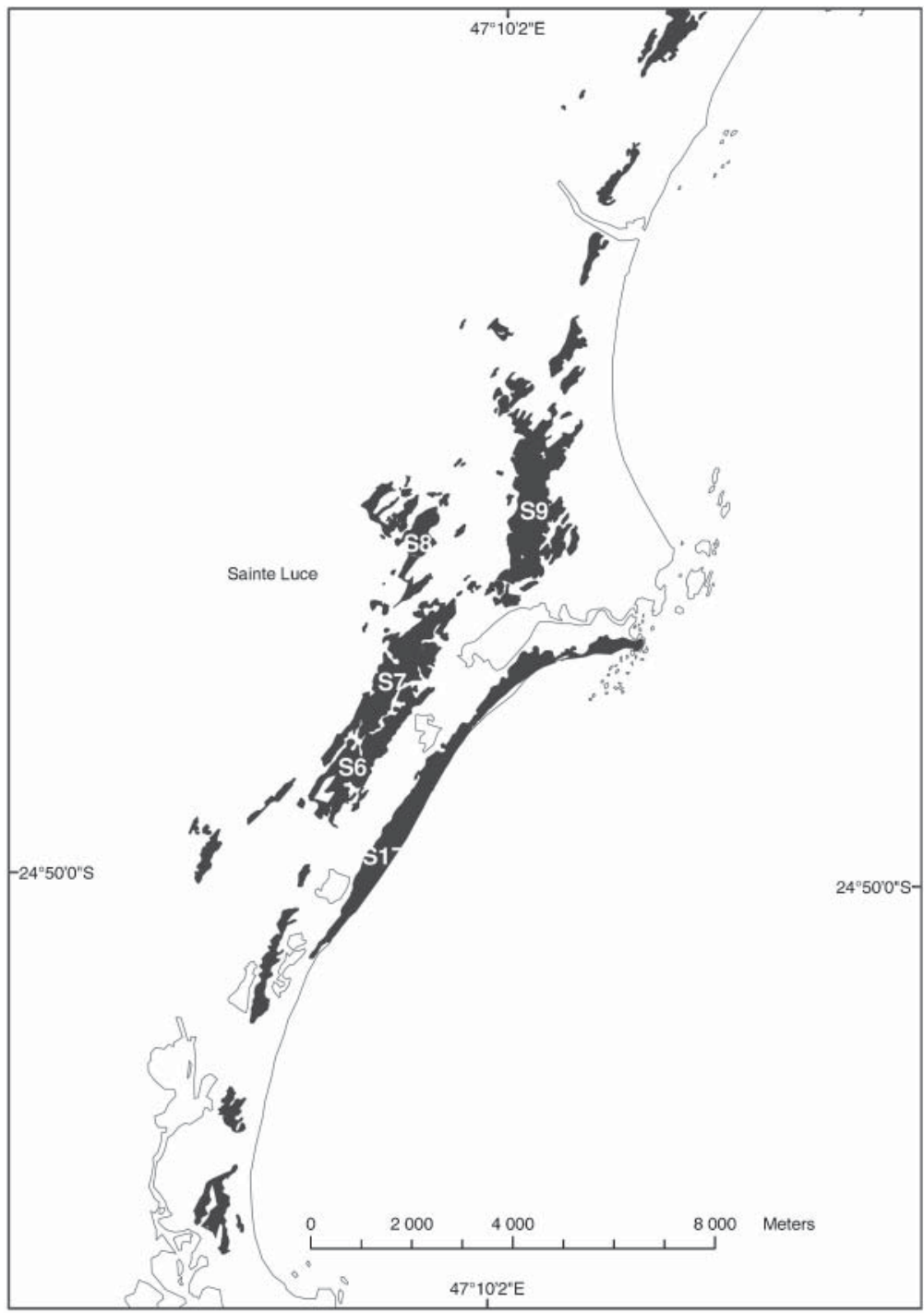

Fig. 2 The largest forest fragments (S6, S7, S8, S9, S17) of the littoral forest of St Luce (see Fig. 1 for location), indicated in black. base to collect the fibres from their leaves, from which traps for crabs and lobster are made, but the logs are often left behind unused. Canoes are dug out of the largest trees, such as ramy Canarium boivinii and vitano (Calophyllum sp.; Table 1) and various species of vine are used for fishing gear.

Hunting also has its impact on forest dynamics, but in contrast to sites further inland (Andohaela, Vohimena; Randriamanalina et al., 2000) the impact of hunting in Sainte Luce is limited because of the importance of fish and shellfish in the local diet and as a major source of income. Bushmeat is only eaten on rare occasions and during traditional events. Nocturnal lemurs, such as Cheirogaleus major, Cheirogaleus medius and the tiny Microcebus rufus, which hibernate in hollow tree trunks, are easily caught. The endemic Eulemur fulvus collaris, which occurs only in south-east Madagascar (Mittermeier et al.,1994) and is categorized as Vulnerable on the IUCN
Red List (IUCN, 2004), is hunted by a traditional technique called tandroho (Randriamanalina et al., 2000) in which a strip of forest $\left(50 \mathrm{~m}^{2}\right)$ is cleared so that gaps in the canopy are too large for the lemurs to cross. Long logs are then placed between both ends of the canopy as the only crossover point, and two snares are set in the middle. This hunting technique could be responsible for an unbalanced sex-ratio in favour of males, reported in fragment S9 (G. Donati, unpubl. data), as in this species females often initiate the travelling. E. f. collaris is also captured by the use of slings, a practice particularly favoured by young men, and probably responsible for the shyness of these lemurs at this site.

Discussion with several local residents suggested that hunting pressure on E.f. collaris declined drastically in S9 because of the presence of researchers (G. Donati, pers. obs.). In the nearby fragment S17 traps were, however, still encountered in September 2000. The endemic 
Table 1 Plant species from Sainte Luce (Fig. 2), by family, with their vernacular names, status, any known uses, number of frugivorous species that feed on them, and whether used as food by local people.

\begin{tabular}{|c|c|c|c|c|c|c|}
\hline Family & Species & Vernacular name & Status $^{1}$ & $\mathrm{Use}^{2}$ & Frugivores $^{3}$ & Food $^{4}$ \\
\hline \multirow[t]{2}{*}{ Anacardiaceae } & Poupartia chapelieri & sisikandrongo & A & $\mathrm{C}$ & 7 & \\
\hline & Protorhus cf. lecomtei & kangy & & & LS & \\
\hline \multirow[t]{3}{*}{ Anonaceae } & Monanthotaxus cf. malacophylla & vahimbotany & C & & & \\
\hline & Polyalthia madagascariensis & fotsivavo & & & 8 & \\
\hline & Polyalthia capuronii & menapeka & & & LS & \\
\hline Apocynaceae & Cabucala madagascariensis & tandrokosy & & & & Fruit \\
\hline Araceae & Typhonodorum lendleyanum & via & & & & Root \\
\hline \multirow[t]{2}{*}{ Araliaceae } & Schefflera rainaliana & voatsilana sp. 1 & & $\mathrm{~F}, \mathrm{M}$ & & \\
\hline & Polyscias sp. & voatsilana sp. 2 & & & 7 & \\
\hline \multirow[t]{5}{*}{ Arecaceae } & Dypsis fibrosa & boakandambo & $\mathrm{L}$ & & LS & \\
\hline & Dypsis nodifera & raotry & $\mathrm{L}$ & & & \\
\hline & Dypsis prestoniana & boakabe & $\mathrm{L}$ & & 9, key? & \\
\hline & Dypsis saintelucei & telopolombilany & $\mathrm{L}$ & & & \\
\hline & Dypsis scottiana & raosy amboza & $\mathrm{L}$ & & 6 & \\
\hline \multirow[t]{3}{*}{ Bignoniaceae } & Ophiocolea delphinensis & akondronala & $\mathrm{C}, \mathrm{E}$ & $\mathrm{U}$ & & Fruit \\
\hline & Phyllarthron madagascariense & zahambe & $\mathrm{E}$ & $\mathrm{C}$ & & \\
\hline & Phyllarthron sp. & zahambe manongaroa & $\mathrm{E}$ & $\mathrm{C}$ & & \\
\hline Burseraceae & Canarium boivinii & ramy & & $\mathrm{C}, \mathrm{M}$ & LS & \\
\hline Canellaceae & Cinnamosna madagascariensis & vahabatra sp. 2 & & & LS & \\
\hline Capparaceae & Crataeva obovata & belataka & $\mathrm{C}$ & & LS & \\
\hline \multirow[t]{4}{*}{ Clusiaceae } & Psorospermum revolutum & harongampanihy & & $\mathrm{F}, \mathrm{M}$ & & Fruit \\
\hline & Calophyllum sp. & vitano & & $\mathrm{C}$ & & \\
\hline & Garcinia chapelieri & haziny tomate & & & LS & \\
\hline & Garcinia cf./aff. madagascariensis & disaky kely & & & LS & \\
\hline Combretaceae & Terminalia fatraea & katrafa & & $\mathrm{C}$ & & \\
\hline Dichapetalaceae & Dichapetalum sp. & vahihazo & & & LS & \\
\hline \multirow[t]{2}{*}{ Ebenaceae } & Diospyros gracilipes & hazomainty blanc & & $\mathrm{F}$ & LS & \\
\hline & Diospyros sp. & hazomainy & $\mathrm{L}$ & $\mathrm{F}$ & LS & \\
\hline Elaeocarpaceae & Elaeocarpus alnifolius & sanga & & & LS & \\
\hline Ericaceae & Vaccinium emirnense & tsilantria & & $\mathrm{C}, \mathrm{F}$ & 9 & Fruit \\
\hline \multirow[t]{2}{*}{ Erythroxylaceae } & Erythroxylum braxifolium & fangora sp. 1 & & $\mathrm{~F}$ & & \\
\hline & Erythroxylum nitidilum & fangora sp. 2 & & $\mathrm{~F}$ & & \\
\hline \multirow[t]{3}{*}{ Euphorbiaceae } & Uapaca ferruginea & voapaky lahy sp. 1 & & $\mathrm{C}, \mathrm{F}$ & 6 & \\
\hline & Uapaca littoralis & voapaky vavy & & $\mathrm{C}, \mathrm{F}$ & 9 & \\
\hline & Uapaca thouarsii & voapaky lahy sp. 2 & $\mathrm{~L}$ & $\mathrm{C}, \mathrm{F}$ & & \\
\hline \multirow[t]{3}{*}{ Fabaceae } & Cynometra cf. cloiselii & mampay & A & $\mathrm{C}$ & & \\
\hline & Phylloxylon xylophylloides & sotro & $\mathrm{E}$ & $\mathrm{C}$ & & \\
\hline & Intsia bijuga & harandrato & & C & & \\
\hline \multirow{4}{*}{ Flacourtiaceae } & Aphloia theiformes & fandramana & $\mathrm{C}$ & & & \\
\hline & Bembicia uniflora & bemalemy & A & $\mathrm{C}, \mathrm{F}$ & & \\
\hline & Homalium louvelianum & ramirisa & & $\mathrm{C}, \mathrm{F}$ & & \\
\hline & Scolopia orientalis & zoramena & $\mathrm{C}$ & $\mathrm{F}$ & 7 & \\
\hline Hypocrataceae & Salacia madagascariensis & voatsimatra & C & & LS & Fruit \\
\hline \multirow[t]{2}{*}{ Icacinaceae } & Apodytes dimidiata & hazomamy marecage & $\mathrm{E}$ & & 9 & \\
\hline & Apodytes sp. nov. & hazomamy an ala & $\mathrm{E}$ & $\mathrm{U}$ & LS & \\
\hline \multirow[t]{2}{*}{ Lauraceae } & Cryptocarya sp. & tavolohazo & & $\mathrm{U}$ & & \\
\hline & Ravensara acuminata & & & $\mathrm{M}$ & & \\
\hline \multirow[t]{2}{*}{ Liliaceae } & Dracaena reflexa var. nervosa & falinandro & $\mathrm{C}, \mathrm{L}$ & $\mathrm{F}, \mathrm{M}$ & & \\
\hline & Dracaena reflexa var. nervosa & tavolobotroka & $\mathrm{C}, \mathrm{L}$ & $\mathrm{F}, \mathrm{M}$ & & \\
\hline Loganiaceae & Anthocleista longifolia & lendemilahy & $\mathrm{C}$ & $\mathrm{C}$ & & \\
\hline Loranthaceae & Bakerella sp. & velomihanto & & & 6 & \\
\hline Melastomataceae & Tristemma mauritianum & voatrotoky & & & & Fruit \\
\hline Meliaceae & Malleastrum mandenense & sarigoavy & $\mathrm{C}, \mathrm{E}$ & & & \\
\hline \multirow[t]{2}{*}{ Monimiaceae } & Tambourissa castri-delphinii & amborabe & & $\mathrm{C}, \mathrm{F}, \mathrm{M}$ & & \\
\hline & Tambourissa purpurea & ambora & & $\mathrm{C}, \mathrm{F}, \mathrm{M}$ & 7 & \\
\hline \multirow[t]{2}{*}{ Moraceae } & Ficus guatteriaefolia & fihamy & & $\mathrm{M}$ & & \\
\hline & Ficus pyrifolia & nonoka & & & 7 & \\
\hline Myricaceae & Myrica spatulata & tsilaka & & M & & \\
\hline
\end{tabular}


Table 1 (continued)

\begin{tabular}{|c|c|c|c|c|c|c|}
\hline Family & Species & Vernacular name & Status $^{1}$ & Use $^{2}$ & Frugivores $^{3}$ & Food $^{4}$ \\
\hline \multirow[t]{2}{*}{ Myristicaceae } & Brochoneura acumineata & mafotra sp. 1 & $\mathrm{C}$ & $\mathrm{C}, \mathrm{M}$ & LS & \\
\hline & Brochoneura madagascariensis & mafotra sp. 2 & $\mathrm{C}$ & $\mathrm{C}, \mathrm{M}$ & LS & \\
\hline Myrsinaceae & Embelia incumbens & taratasy & & M & & \\
\hline \multirow[t]{4}{*}{ Myrtaceae } & Eugenia cloiselii & ropasy sp. 1 & $\mathrm{C}, \mathrm{E}$ & $\mathrm{C}, \mathrm{F}, \mathrm{M}$ & & \\
\hline & Eugenia sp. & ropasy sp. 2 & & $\mathrm{C}, \mathrm{F}, \mathrm{M}$ & LS & \\
\hline & Syzigium sp. 1 & rotry ala & & $\mathrm{C}$ & 7 & Fruit \\
\hline & Syzigium sp. 2 & rotry mena & & $\mathrm{C}$ & 10,key? & Fruit \\
\hline \multirow[t]{4}{*}{ Oleaceae } & Jasmimum kitchingii & vahifotsy kely & $\mathrm{C}$ & & & \\
\hline & Noronhia cf lanceolata & hazondraotry & & M & & \\
\hline & Noronhia sp. 1 & belavenoka & & M & & \\
\hline & Olea sp. & vahabatra sp. 1 & A & M & 7 & \\
\hline \multirow[t]{3}{*}{ Pandanaceae } & Pandanus dauphinensis & vakoanala & $\mathrm{A}$ & $\mathrm{C}$ & LS & \\
\hline & Pandanus aff. longistylus & fandranabo & & $\mathrm{C}$ & LS & \\
\hline & Pandanus rollotii & fandranabotonboky & & $\mathrm{C}$ & LS & \\
\hline Podocarpaceae & Podocarpus madagascariensis & harambilo & & $\mathrm{C}, \mathrm{F}, \mathrm{M}$ & & \\
\hline Rhopalocarpaceae & Rhopalocarpus coriaceus & tsilavimbinanto & & & LS & \\
\hline \multirow[t]{7}{*}{ Rubiaceae } & Canthium sp. & fantsikaitra sp. 1 & & $\mathrm{C}, \mathrm{F}, \mathrm{M}$ & & \\
\hline & Canthium variistipule & fantsikaitramainty & $\mathrm{C}$ & $\mathrm{C}, \mathrm{F}, \mathrm{M}$ & 6 & Fruit \\
\hline & Ixora sp. & unknown & $\mathrm{C}$ & $\mathrm{U}$ & & \\
\hline & Plectronia densiflora & fantsikaitra sp. 2 & & M & & \\
\hline & Psychotria sp. & tanatananala & & $\mathrm{F}$ & & \\
\hline & Hyperacanthus mandenensis & taholagna & & $\mathrm{U}$ & & Fruit \\
\hline & Tricalysia cf. cryptocalyx & hazongalala & & $\mathrm{F}$ & & \\
\hline Rutaceae & Vepris eliotii & lahinampoly & $\mathrm{C}, \mathrm{E}$ & $\mathrm{C}, \mathrm{F}, \mathrm{M}$ & 6 & \\
\hline \multirow[t]{2}{*}{ Sapindaceae } & Macphersonia radlkoferi & sanirambaza & & $\mathrm{U}$ & & \\
\hline & Plagioscyphus jumelei & ambirimarika pionair & & $\mathrm{U}$ & & \\
\hline \multirow[t]{3}{*}{ Sarcolaenaceae } & Leptolaena multiflora & fotombavy & $\mathrm{C}$ & $\mathrm{C}, \mathrm{F}$ & & \\
\hline & Sarcolaena multiflora & meramaintso & $\mathrm{C}, \mathrm{L}$ & $\mathrm{C}, \mathrm{F}$ & 9 & Fruit \\
\hline & Schizolaena elongata & fotondahy & & C & & \\
\hline Saxifragaceae & Brexia sp. & kambatrikambatri & $\mathrm{C}$ & & & \\
\hline Sphaerosepalaceae & Rhopalocarpus coriaceus & tsilavimbinanto & $\mathrm{C}$ & $\mathrm{U}$ & & \\
\hline Strelitziaceae & Ravenala madagascariensis & ravenala & & $\mathrm{C}, \mathrm{M}$ & & \\
\hline Taccaceae & Tacca leontopetaloides & tavolo & & & & Root \\
\hline Theaceae & Asteropeia multiflora & fanolafotsy & & $\mathrm{C}, \mathrm{F}, \mathrm{M}$ & & \\
\hline Verbenaceae & Vitex chrysomallium & nofotrako & $\mathrm{L}$ & $\mathrm{C}$ & & \\
\hline
\end{tabular}

${ }^{1}$ A, abundant; C, common; E, endemic; L, typical littoral forest species. Data from Koechlin (1974), Lewis Environmental Consultants (1992a), Rabevohitra et al.(1996), Razafimizanilala (1996), Dumetz (1999) and QMM (2001)

${ }^{2} \mathrm{C}$, construction wood; F, fuelwood; $\mathrm{M}$, medicinal use; $\mathrm{U}$, unknown use

${ }^{3}$ Number of plant species consumed by frugivores; LS, large-seeded plant species for which Eulemur fulvus collaris is the only seed disperser; key?, potential keystone species during periods of fruit scarcity.

${ }^{4}$ Food species for people, with indication of plant part eaten

Malagasy flying fox Pteropus rufus, categorized as Vulnerable on the IUCN Red List (IUCN, 2004), is hunted at the colony's roost site (S6; Fig. 2). Slings, long branches and stones were often found under their roost site and as a consequence of this hunting pressure the colony moved their roost site twice in 2000 (Bollen \& Van Elsacker, 2002). Terrestrial birds are trapped using snares or other simple systems placed on the ground. Fruit pigeons (Treron australis and Alectroenas madagascariensis), parrots (Coracopsis vasa and Coracopsis nigra) and bulbuls Hypsipetes madagascariensis are hunted with arrows or slings. Small branches covered with sticky latex, placed in Ficus or other fruiting trees by young men, are also used to catch fruit pigeons. Tenrecs (Setifer setosus and
Tenrec ecaudatus) are hunted with the aid of dogs at dusk. Hunting is mainly for food but occasionally animals are traded regionally for pets, in particular E. f. collaris and Coracopsis spp. (A. Bollen, pers. obs.).

The future extraction of ilmenite by QIT Madagascar Minerals (QMM) is an imminent threat. The littoral forests of Sainte Luce, Mandena and Petriky lie within the QMM concession zone. Mining activities will start in 2009 in Mandena and 20-45 years later in Petriky and Sainte Luce, respectively, lasting up to 60 years (M. Vincelette, pers. comm.). In Mandena, Sainte Luce and Petriky 62.8, 661.8 and 705.8 ha, respectively, of the remaining littoral forest will be lost (QMM, unpubl. data). However this impact is partially mitigated by a 
large investment in environmental impact assessment studies, instalment of tree nurseries and plantations, establishment of seed banks, and extensive research into reforestation. QMM also cooperates with the Department of Water and Forestry, Ministry of Environment and local communities to ensure the establishment of conservation zones in the mining area.

\section{Impacts on the ecosystem and on seed dispersers}

Plant-frugivore interactions are important components of complex forest communities, and seed dispersal by vertebrates is a key process in vegetation dynamics and recovery (Wallace \& Painter, 2002). Frugivores play a vital role in the maintenance of biodiversity in tropical forests, where they constitute a large proportion of the vertebrate biomass (Fleming et al., 1987), and zoochorous tree species make up the bulk of tropical plant species (Howe \& Smallwood, 1982). Loss of fruit-frugivore interactions can thus have profound consequences (Corlett, 1998). Many animal species in Sainte Luce rely on fruit as an essential food resource and also provide valuable dispersal services to many fruit-bearing plants (Bollen et al., 2004a; Table 1). As Malagasy forests become more fragmented the remaining patches become increasingly isolated and inaccessible to arboreal lemur species (Ganzhorn et al., 2001). As a consequence gene flow and seed dispersal between patches may become critical for long-term survival of many plant species.

Large frugivores are often the most vulnerable to habitat fragmentation (Johns \& Skorupa, 1987; Kannan \& James, 1999) and this is the case for E. f. collaris in Sainte Luce, where the species is only present in the largest fragments, S9 (377 ha) and S17 (237 ha). E. f. collaris is also particularly important for dispersal of the seeds of numerous plant species (Bollen et al., 2004a). We found this to be the only frugivore in these forests able to swallow and thus disperse large seeds (up to $16.5 \mathrm{~mm}$ diameter; Ganzhorn et al., 1999; Bollen et al., 2004a; Table 1). Local extirpation of E. f. collaris could lead to the eventual loss of those plant species that are dependent on it for seed dispersal. Other specialist frugivores, such as $P$. rufus, T. australis and $A$. madagascariensis are vulnerable as well, in particular when important food sources are logged (Table 1). Frugivorous birds and flying foxes are the most important mobile seed dispersers at Sainte Luce, transporting seeds of numerous species into grasslands and early successional vegetation. The simple structure of these communities poses less of a barrier to birds and bats than to arboreal lemurs.

Our studies (Bollen 2003; Bollen et al., 2004a, 2004b) found no evidence for coevolution, nor any strong indication of the existence of dispersal syndromes at Sainte
Luce. A syndrome (Van der Pijl, 1969) is a set of morphological and nutritional traits that determine bird, bat and mammal dispersed fruits. However, we found that there is substantial dietary overlap among frugivore species (Bollen, 2003). Most frugivores seem to be opportunistic in fruit selection, eating whatever is available given the limitation of fruit and seed size and certain feeding preferences (Bollen et al., 2004a, 2004b).

\section{Protection measures}

\section{Forest}

Sainte Luce contains some of the most intact littoral forest fragments on sand, which differ in floristic diversity from sublittoral forest fragments on laterite, such as S8 (Fig. 2), and from the inland montane forest of Vohimena (Rabevohitra et al., 1996; Dumetz, 1999). Several studies in Madagascar have demonstrated that protection of a few large fragments as opposed to several small ones will maximize the conservation of reptiles and amphibians (Ramanamanjato, 2000), birds (Raherilalao, 2001) and lemurs (Ganzhorn et al., 2000). The protection of the remaining primary forest is crucial for the maintenance of the present biodiversity. Ganzhorn \& Schmid (1998) showed that 40-year old secondary dry forests in western Madagascar are unlikely to provide a suitable habitat even for the smallest, least threatened, lemur species such as Microcebus murinus. Although studies still have to confirm this, it is also likely to be the case for the littoral forest.

Conservation priorities for the remaining forest fragments have been categorized based on 10 criteria: size, integrity, biodiversity, representativity, manageability, endemicity (local, regional and national), number of rare, threatened and vulnerable species, protected area, complementarity and natural borders (QMM, 2001). At Sainte Luce the fragments S9 and S17 (Fig. 2) have the highest conservation priority and may act as reservoirs from where indigenous species of flora and fauna can colonize new habitats. These forest fragments are different from each other in appearance and floral composition and harbour a large faunal and floral diversity (Lewis Environmental Consultants, 1992). They are representative of the south-eastern littoral forest ecosystem. Additionally, protection of the flying fox roost site in S6 is important as this species is the only long-distance seed disperser. These three fragments comprise c. 1,000 ha of littoral forest, are within close proximity, and include littoral forest, mangroves, dunes and marshes, sandy beaches, a lake and an estuary. The proposed conservation zones (QMM, 2001) involve 190 ha of S9 and all of S17 (237 ha); their main purpose is to protect primary forest, with the banning of all logging, hunting and tavy 
within the fragments. The establishment of S9 and S17 as conservation zones has been agreed by the local communities, the Department of Water and Forestry, QMM and the NGO Azafady, and is based on dinas. From 1996 the Gestion Local Securise legislation incorporated dinas, the primary local rule making, into official management (Journal Officiel de la République de Madagascar, LOI $N^{\circ}$ 2000-027). The Sainte Luce dina has been accepted by all local stakeholders and the co-management plan is expected to be signed at the end of 2005. Active protection of the forest fragments S9 and S17 will then be ensured, as these areas will be officially classified as protected areas in the Système des Aires Protégées de Madagascar. Cooperation with local people in decisionmaking and control systems, as promoted by the Malagasy National Environment Action Plan (1990-2005), will be an essential feature if this conservation plan is to succeed.

\section{Animals}

The effects of forest fragmentation on a given species are related to its tolerance to habitat change and its capability to use the grasslands, shrublands and wetlands surrounding forest fragments. E. f. collaris, almost exclusively arboreal, is particularly vulnerable as it appears to be reluctant to cross open areas (G. Donati, pers. obs.), thus increasing the problems of inbreeding depression for the remaining populations. Moreover, because of the spatio-temporal patchiness of its food resources (A. Bollen \& G. Donati, unpubl. data) E. f. collaris needs large home ranges (up to $100 \mathrm{ha}$ ) and covers long distances daily (1,500-3,500 m; Donati, 2002). At present, fragments S9 and S17 are important refuges for E. f. collaris (Donati, pers. obs.). Several groups (a total of 28 individuals) were translocated in 2000 and 2001 in Mandena (Fig. 1). They were captured from the fragment M3-M4 (100 ha), which was exploited for charcoal, and transferred to the Conservation Zone in Mandena (M15-M16, 230 ha). Despite the initial loss of some individuals the lemurs seem to have adapted to their new habitat and post-monitoring studies indicate that the animals were able to survive and reproduce normally (G. Donati, pers. obs.). In 2003 the total number of E.f. collaris in M15-M16 was estimated to be $c .34$ individuals. Unfortunately, in early 2004 at least seven fossa Cryptoprocta ferox, the large endemic viverrid that preys extensively on lemurs, were recorded in the Mandena conservation zone and killed $>6$ E. f. collaris (Donati et al., unpubl. data), thus compromising the success of the translocation. However, translocation and reintroduction of primates, especially in rescue situations such as in Mandena, are becoming increasingly important conservation tools (Soorae \& Baker, 2002).
Nocturnal lemur species are still present even in the smaller forest fragments in Sainte Luce (Ganzhorn et al., 2000). However, they are unable to cross deforested areas and are therefore threatened by inbreeding depression and their seed dispersal services are also limited to within single forest fragments. P. rufus, however, may cover long distances and rely on resources collected in other forest areas (Bollen \& Van Elsacker, 2002). Restriction of access to the roost is required for conservation of P. rufus. Frugivorous birds are not restricted to particular fragments and seem to be abundantly present in both small and large fragments as well as intact and degraded ones (Watson et al., 2004).

\section{Tree species}

Phenological data show that frugivores in the littoral forest face unpredictable periods of fruit abundance and scarcity (Bollen \& Donati, 2005). We were unable to identify the keystone species (sensu Terborgh, 1986) for this forest but there are several important food species for frugivores (Table 1), including Syzigium sp. 2 (Myrtaceae) and Dypsis prestoniana (Arecaceae). Both species fruit when overall fruit availability is low, produce large fruit crops and are eaten by all frugivores present in Sainte Luce (Table 1). For example, $80 \%$ of the time E.f. collaris spent feeding in June 2000 was on Syzigium sp. 2, and 20\% of time spent feeding in April was on Dypsis prestoniana (Donati, 2002). Because of high intercorrelation of all phenophases (floral reproductive phases), no alternative food sources (such as young leaves or flowers) are available for the animals during these periods, and they therefore rely heavily on only a few fruiting species. Protection measures and possibly ex situ conservation may be needed for these plant species that contribute disproportionately to the diets of certain animal species at a time of year when alternative sources are unavailable.

\section{Corridors}

Because of high levels of degradation and fragmentation, active protection of the remaining intact forest fragments in south-east Madagascar is insufficient to conserve and restore this ecosystem. Furthermore, natural regeneration via secondary forests is generally too slow to counteract the loss of primary forests (Ganzhorn et al., 1999). The creation of corridors (Beier \& Noss, 1998) is considered a conservation priority for this area (Ganzhorn et al., 1997; Holloway, 2004). Corridors promote increased plant and animal movement among patches, which enhances population viability and recolonization, and increases pollination and seed dispersal (Beier \& Noss, 1998; Tewksbury et al., 2002). However, while some 
species readily move between fragments using habitat corridors, others do not (Chapman \& Peres, 2001). In 1999 a corridor was created between the forest fragments M4 and M5 in the Mandena area by planting a mixture of endemic (20\%) and exotic fast-growing species $(80 \%)$ to accelerate the formation of a bridge for tree-dwelling animals. Unfortunately, the corridor was recently burned down, together with most of the two forest fragments. In Sainte Luce the three largest fragments (S9, S7 \& S17) are relatively close to each other, and the establishment of corridors to connect these fragments needs to be considered. However, the establishment of corridors in this area is challenging because of the presence of roads, swamps and rivers between fragments.

\section{Plantations}

Unassisted succession restores biomass better than it does biodiversity (Corlett, 2002), and dependence entirely on natural seed dispersal may result in secondary forest dominated by a particular subset of the forest flora. Large-seeded plant species (e.g. Canarium boivinii, Diospyros sp., Apodytes sp. nov.; Table 1) that have few seed dispersers are less easily dispersed and may require planting for re-establishment (Wunderle, 1997; Kitamura et al., 2002; Ingle, 2003). By planting both native and exotic species regeneration can be promoted and at the same time this can provide alternative wood sources. Experiments in a tree nursery have shown that a variety of non-invasive exotic trees such as Eucalyptus, Acacia and Casuarina spp. (QMM, 2001) may be suitable for landscape restoration in this area. Planting of these tree species may accelerate natural forest succession by ameliorating impoverished soil and understorey microclimatic conditions, suppressing invasive dominant grasses, improving soil fertility and nutrient availability, and attracting seed dispersers (Corlett, 2002). There are $c$. 30 ha of plantations, on either private or state property, close to Mandena, and QMM have created 300 ha of plantations around Mandena and 2 ha in Sainte Luce and have a commitment to establish 100 ha of plantations each year (M. Vincelette, pers. comm.). Mixed species plantations in Ampijoroa have been shown to provide acceptable habitats for the majority of the lemur species there (Ganzhorn, 1987). In Mandena C. medius and Microcebus murinus have been observed to feed on the flowers of the exotic Melaleuca quinquenervia (Myrtaceae; QMM, 2001). In other eastern sites even the larger Eulemur spp. have been seen to rely on Eucalyptus flowers (Ganzhorn, 1985; Overdorff, 1988). However, the floristic diversity of plantations is limited and may not provide food year-round for all lemur species (Ganzhorn, 1987; Ganzhorn \& Abraham, 1991). Therefore, plantations should ideally border natural forests. Planting important fruiting trees in corridors, plantations or clearings is another way to enhance reforestation by attracting frugivores and stimulating the seed dispersal they provide. Dietary data on frugivores should be taken into account when choosing fruit species to be included in planting projects (Table 1).

\section{Conclusions}

The littoral forest of the Fort Dauphin region is being cleared at an alarming rate and is not yet represented in protected areas. The declaration of the Malagasy President Ravolomanana, at the Fifth World Parks Congress in Durban, to triple the protected areas in Madagascar to 6 million ha by 2009 will change this situation (IRG-PAGE, 2001). Understanding forest dynamics and plant-animal interactions in this degraded ecosystem is essential if existing forests are to be conserved and deforestation is to be slowed down or halted. Besides active protection measures, there is also great need for integrated management combining research, conservation and developmental aid. Firstly, there is a need for alternative fuel and wood sources, which could be provided by plantations of fast-growing non-invasive species. Secondly, income generating activities such as small-scale ecotourism, butterfly farming and beekeeping are also required. Finally, environmental education is required in the villages of the region.

Recruitment of local people and environmental education in Mandena, promoted by QMM in the last decade, have resulted in the halting of deforestation in the conservation zone M15-M16. Ecotourism has also been functioning since 2004. In Sainte Luce environmental and social programmes are conducted both by QMM and Azafady. QMM has built a school, recruited local staff and invested in forest-related activities such as beekeeping. There have been recent reductions in hunting and forest clearing in the conservation zones established by the local dina (G. Donati, pers. obs.). Nevertheless, substantial effort is needed to provide the local people of Sainte Luce with alternative resources to ensure protection of the remaining biodiversity of the littoral forest.

\section{Acknowledgements}

We thank the Commission Tripartite of the Malagasy Government, the Ministère des Eaux et Forets, QMM and Missouri Botanical Garden at Antananarivo for their collaboration and permission to work in Madagascar. Thanks to Manon Vincelette, Jean-Baptiste Ramanamanjato, Laurent Randrihasipara, Johny Rabenantoandry and Faly Randriatafika of the QMM Environmental team for providing information on environmental policy in the littoral forest. We are grateful to Jörg Ganzhorn, 
Linda van Elsacker and Silvana Borgognini-Tarli for their support, and two anonymous reviewers for useful suggestions. $A B$ was supported by a grant from the Belgian Fund for Scientific Research. GD was supported by a doctoral grant of the Italian Ministry for Scientific Research and the University of Pisa.

\section{References}

Beier, P. \& Noss, R.F. (1998) Do habitat corridors provide connectivity? Conservation Biology, 12, 1241-1252.

Bollen, A. (2003) Fruit-frugivore interactions in a Malagasy littoral forest: a community-wide approach of seed dispersal. PhD thesis, University of Antwerp, Belgium.

Bollen, A. \& Donati, G. (2005) Phenology of the littoral forest of Sainte Luce, south-eastern Madagascar. Biotropica, 37, 31-42.

Bollen, A. \& Van Elsacker, L. (2002) Feeding ecology of Pteropus rufus (Pteropodidae) in the littoral forest of Sainte Luce, SE Madagascar. Acta Chiropterologica, 4, 33-47.

Bollen, A., Van Elsacker, L. \& Ganzhorn, J.U. (2004a) Relations between fruits and disperser assemblages in the littoral forest of south-east Madagascar: a community level approach. Journal of Tropical Ecology, 20, 599-612.

Bollen, A., Van Elsacker, L. \& Ganzhorn, J.U. (2004b) Tree dispersal strategies in the littoral forest of Sainte Luce (SE Madagascar). Oecologia, 139, 604-616.

Chapman, C.A. \& Onderdonk, D.A. (1998) Forests without primates: primate/plant codependency. American Journal of Primatology, 45, 127-141.

Chapman, C.A. \& Peres, C.A. (2001) Primate conservation in the new millennium: the role of scientists. Evolutionary Anthropology, 10, 16-33.

Corlett, R.T. (1998) Frugivory and seed dispersal by vertebrates in the Oriental (Indomalayan) region. Biological Review, 73, 413-448.

Corlett, R.T. (2002) Frugivores and seed dispersal in degraded tropical East Asian landscapes. In Seed Dispersal and Frugivory: Ecology, Evolution and Conservation (eds D.J. Levey, R.W. Silva \& M. Galetti), pp. 451-465. CABI Publishing, Wallingford, UK.

Donati, G. (2002) L'attivita' e le sue correlate ecologiche nel lemure bruno dal collare, Eulemur fulvus collaris (Lemuridae), nella foresta litorale di Ste Luce (Fort-Dauphin, Madagascar). $\mathrm{PhD}$ thesis, Pisa University, Italy.

Dumetz, N. (1999) High plant diversity of lowland rainforest vestiges in eastern Madagascar. Biodiversity and Conservation, 8, 273-315.

Du Puy, D.J. \& Moat, J.F. (1998) Vegetation mapping and classification in Madagascar (using GIS): implications and recommendations for the conservation of biodiversity. In Chorology, Taxonomy and Ecology of the Floras of Africa and Madagascar (eds C.R. Huxley, J.M. Lock \& D.F. Cutler), pp. 97-117. Royal Botanic Gardens, Kew, UK.

Fleming, T.H., Breitwitsch, R. \& Whitesides, G.H. (1987) Patterns of tropical frugivore diversity. Annual Review of Ecology and Systematics, 18, 91-109.

Ganzhorn, J.U. (1985) Utilization of eucalyptus and pine plantations by brown lemurs in the eastern rainforest of Madagascar. Primate Conservation, 6, 34-35.

Ganzhorn, J.U. (1987) A possible role of plantations for primate conservation in Madagascar. American Journal of Primatology, 12, 205-215.
Ganzhorn, J.U. \& Abraham, J.P. (1991) Possible role of plantations for lemur conservation in Madagascar: food for folivorous species. Folia Primatologica, 56, 171-176.

Ganzhorn, J.U., Fietz, J., Rakotovao, E., Schwab, D. \& Zinner, D. (1999) Lemurs and the regeneration of dry deciduous forest in Madagascar. Conservation Biology, 13, 794-804.

Ganzhorn, J.U., Goodman, S.M., Ramanamanjato, J.-B., Ralison, J., Rakotondravony, D. \& Rakotosamimanana, B. (2000) Effects of fragmentation and assessing minimum viable populations of lemurs in Madagascar. In Isolated Vertebrate Communities in the Tropics (ed. G. Rheinwald), pp. 265-272. Proceedings of the 4th International Symposium, Bonn, Germany.

Ganzhorn, J.U., Lowry, P.P., Schatz, G.E. \& Sommer, S. (2001) The biodiversity of Madagascar: one of the world's hottest hotspots on its way out. Oryx, 35, 346-348.

Ganzhorn, J.U., Malcomber, S., Andrianantoanina, O. \& Goodman, S.M. (1997) Habitat characeristics and lemur species richness in Madagascar. Biotropica, 29, 331-343.

Ganzhorn, J.U. \& Schmid, J. (1998) Different population dynamics of Microcebus murinus in primary and secondary deciduous dry forest of Madagascar. International Journal of Primatology, 19, 785-796.

Green, G. \& Sussman, R. (1990) Deforestation history of the eastern rain forests of Madagascar from satellite images. Science, 248, 212-215.

Holloway, L. (2004) Ecosystem restoration and rehabilitation in Madagascar. Ecological Restoration, 22, 113-119.

Howe, H.F. \& Smallwood, J. (1982) Ecology of seed dispersal. Annual Review of Ecology and Systematics, 13, 201-228.

Ingle, N.R. (2003) Seed dispersal by winds, birds, and bats between Philippine montane rainforest and successional vegetation. Oecologia, 134, 251-261.

IRGE-PAGE (2001) Priorisation des habitats pour la conservation de la biodiversité dans la région de l'Anosy. Equipe suivi Ecologique IRG-PAGE et Groupe Technique Biodiversité, Fort Dauphin, Madagascar.

IUCN (2004) 2004 IUCN Red List of Threatened Species. IUCN, Gland, Switzerland [http:/ / www.redlist.org, accessed 14 January 2005].

Johns, A.D. \& Skorupa, J.P. (1987) Responses of rain-forest primates to habitat disturbance: a review. International Journal of Primatology, 8, 157-191.

Kannan, R. \& James, D.A. (1999) Fruiting phenology and the conservation of the great pied hornbill (Buceros bicornis) in Western Ghats of Southern India. Biotropica, 31, 167-177.

Kitamura, S., Yumoto, T., Poonswad, P., Chuailua, P., Plongmai, K., Maruhashi, T. \& Noma, N. (2002) Interactions between fleshy fruits and frugivores in a tropical seasonal forest in Thailand. Oecologia, 133, 559-572.

Koechlin, J., Guillaumet, J.L. \& Morat, P. (1974) La forêt dense humide sempervirente de basse altitude et la foret littorale. In Flore et Vegetation de Madagascar (eds J. Koechlin, J.L. Guillaumet \& P. Morat), pp. 105-165. J. Cramer, Vaduz, Liechtenstein.

Lewis Environmental Consultants (1992) Madagascar Minerals Project. Preliminary Environment Impact Assessment Study. Appendix III: Flora. Madagascar Minerals Project, Antananarivo, Madagascar.

Lowry, P. (2001) Réévaluation et mise à jour des données sur les espèces prioritaires de la flore endémique de Mandena, region de Taolagnaro, Madagascar. Internal Report, Madagascar.

McConkey, K.R. \& Drake, D.R. (2002) Extinct pigeons and declining bat populations: are large seeds still being dispersed in the tropical Pacific? In Seed dispersal and 
Frugivory: Ecology, Evolution and Conservation (eds D.J. Levey, R.W. Silva \& M. Galetti), pp. 381-395. CABI Publishing, Wallingford, UK.

Mittermeier, R.A., Myers, N., Thomsen, J.B., da Fonseca, G.A.B. \& Olivieri, S. (1998) Global biodiversity hotspots and major tropical wilderness areas. Conservation Biology, 12, 516-520.

Mittermeier, R.A., Tattersall, I., Konstant, W.R., Meyers, D.M. \& Mast, R.B. (1994) Lemurs of Madagascar. Conservation International, Washington, DC, USA.

Overdorff, D. (1988) Preliminary report on the activity cycle and diet of the red-bellied lemur (Lemur rubriventer) in Madagascar. American Journal of Primatology, 16, 143-153.

QMM (QIT Madagascar Minerals S.A.) (2001) Projet Ilménite: Etude d'impact social et environmental. Unpublished Report. QMM, Antananarivo, Madagascar.

Rabevohitra, R., Lowry, P.P., Randrianjafy, H. \& Razafindrianilana, N. (1996) Rapport sur le projet 'Assesment of Plant Diversity and Conservation Importance of East Coast Low Elevation Malagasy Rain Forests'. Centre National de la recherché appliquée au développement rural CENRADERU-FOFIFA. Missouri Botanical Garden, USA.

Raherilalao, M.J. (2001) Effets de la fragmentation de la forêt sur les oiseaux autour du parc national de Ranomafana (Madagascar). Revue d'Ecologie (Terre et Vie), 56, 389-406.

Ramanamanjato, J.-B. (2000) Fragmentation effects on reptile and amphibian diversity in the littoral forest of southeastern Madagascar. In Isolated Vertebrate Communities in the Tropics (ed. G. Rheinwald), pp. 297-308. Proceedings of the 4th International Symposium, Bonn, Germany.

Randriamanalina, M.H., Rafararano, L., Babary, L. \& Laha, R. (2000) Rapport des enquêtes sur les chasses dans les fokotany d'Ivondro, d'Erara et d'Etsilesy. Lemur News, 5, 11-14.

Razafimizanilala, A.A.M. (1996) Introduction à l'étude écologique des forêts sublittorales de Sainte-Luce (Tolagnaro). MSc thesis, Université d'Antananarivo, Madagascar.

Soorae, P.S. \& Baker, L.R. (2002) Re-introduction news: special primate issue. Newsletter of the IUCN/SSC Re-introduction Specialist Group, Abu Dhabi, UAE, 21, 1-60.
Terborgh, J. (1986) Community aspects of frugivory in tropical forests. In Frugivores and Seed Dispersal (eds A. Estrada \& T.H. Fleming), pp. 371-384. W. Jung, Dordrecht, The Netherlands.

Tewksbury, J.J., Levey, D.J., Haddad, N.M., Sargent, S., Orrock, J.L., Weldon, A., Danielson, B.J., Brinkerhoff, J., Damschen, E.I. \& Townsend, P. (2002) Corridors affect plants, animals and their interactions in fragmented landscapes. Proceedings of the National Academy of Sciences, 99, 12923-12926.

Van der Pijl, J. (1969) Principles of Dispersal in Higher Plants. Springer Verlag, Berlin, Germany.

Wallace, R.B. \& Painter, R.L.E (2002) Phenological patterns in a southern Amazonian tropical forest: implications for sustainable management. Forest Ecology and Management, 160, 19-33.

Watson, J.E.M., Whittaker, R.J. \& Dawson T.P. (2004) Avifaunal responses to habitat fragmentation in the threatened littoral forests of south-eastern Madagascar. Journal of Biogeography, 31, 1791-1807.

Wunderle, J.M. (1997) The role of animal seed dispersal in accelerating native forest regeneration on degraded tropical lands. Forestry Ecology and Management, 99, 223-235.

\section{Biographical sketches}

An Bollen studied community ecology in the littoral forests of south-east Madagascar from 1999 to 2003, focusing mainly on seed dispersal ecology and on plant-animal interactions. She was then involved in the Socotra Conservation and Development Programme, providing ecological monitoring. Currently she is working on biodiversity issues at the UNEP Headquarters for Asia and the Pacific in Bangkok.

Giuseppe Donati has studied the behavioural ecology of brown lemurs in various habitats of Madagascar and, since 2003 , the responses of collared brown lemurs to translocation and forest degradation. 